\title{
Investigating and Prioritizing Factors Affecting Technology Selection Using Multi Criteria Decision Making Methods in the National Iranian Petrochemical Company
}

\author{
Seyed Hossein Nouri, Tahmoures Sohrabi*
}

\begin{abstract}
Technology can be considered as the most important factor in changing human experiences. Much of the success of most top companies in the field of competition rests on innovative activities that often rely on technology. On the other hand, defining valid and reliable as well as measurable indicators is necessary in order to make the most accurate decision. This refers to the famous saying that anything that can be measured can be managed. Therefore, using various scientific sources, the present study seeks to identify indicators of appropriate technology selection and then, prioritize them using multi-criteria decision making methods in the National Iranian Petrochemical Company. For this purpose, first important factors have been identified by studying the research literature and utilizing experts' opinion gathered and aggregated by Delphi method. Then, by these factors have been ranked by screening and final identification through a hybrid approach of TOPSIS and Shannon entropy. According to the obtained results, technology efficiency has the highest priority among the factors which shows that in technology with the highest level of efficiency must be transferred and used in petrochemical industry. The competitive effects of technology have the lowest priority which shows that it is the least impact for technology transfer in this industry, and it need less attention from the industry practitioners.
\end{abstract}

Keywords: MADM; Petrochemical Industry; Shannon Entropy; Technology Selection; TOPSIS Method

\section{INTRODUCTION}

As the most important factor in changing human experiences [1], technology refers to the knowledge, skills, techniques and tools needed to convert resources into products [2]. The performance of each company is affected by six important economic factors Including capital, manpower, management, products, resources and technology. In today's markets with increasing changes, the ability of organizations to use new technologies is a sustainable competitive advantage [3]. The major part of the success of most successful companies relies on innovative activities that are often based on technology [4]. On the other hand, more accurate decision-making requires the definition of indicators with a high level of validity and reliability, as well as the possibility of measuring them. Because it is well known in management that anything that can be measured can be managed. Accordingly, utilizing various scientific literature, the present study seeks to develop indicators to select the appropriate technology and then prioritize them using multi-criteria decision making methods.

\subsection{Research Problem Statement and Literature Review}

Today, due to the issue of rising costs, the complexity technological change, and global competition and technology resources, the strategic importance of technology has received much attention $[1,5]$. Hence, playing a vital role in business, technology causes creating and maintaining the core competencies of an organization for better performance than competitors and business success [6]. Organizations must be able to select the right technologies to be competitive and adapt to emerging technologies.

Lack of accurate and scientific identification and selection of technologies is one of the main problems of organizations. It is mostly due to their emphasis on key indicators such as cost or revenue, which are not the only factors to achieve organizational success and development. One of the main and key elements of technology strategy is the selection of technologies for development. The technology selection for development refers to identify those technologies that need to be upgraded, or in other words, not suitable for the organization and there is a gap between the current and the desired situation regarding them. Due to the importance of this issue, the present study aimed to identify and prioritize technology selection indicators in the Iranian National Petrochemical Company. The research literature and background are presented in the following section.

A strategic technology planning model have been developed by Reshnavadi and Rouhollahi (2018) in Iranian petrochemical industry using network analysis process that macro goals and strategies are significantly related to industry technology strategies and alternatives and the contribution of each in achieving the ultimate goals is determined by sensitivity analysis. The vision of change and its effects on criteria and alternatives have been created to deal with change, scenarios and have been used for decision making. The process of producing olefins and paraffin, polymer, Nano composites, polymer membranes and membrane and hybrid bioreactors, polyethylene terephthalate, methanol synthesis catalyst and acetic acid synthesis catalyst have been selected as the technology priorities of the petrochemical industry [7].

The criteria of technology suppliers' selection have been identified and prioritized in the study conducted by Eskandari et al. (2017) in industry in the Arak Petrochemical Company. In this paper, PESTLE / SWOT analysis is used to identify internal and external factors affecting the technology supplier selection system. These factors are classified into six categories of political, economic, social, technical, legal, and environmental, and then divided according to their positive or negative effect on the system. Finally, these factors are provided for ranking using the fuzzy VIKOR method. These 
factors are then used for the purpose of technology suppliers' selection in Arak Petrochemical Company [8].

Green technology evaluation and selection in Iran's cement industry to reduce environmental pollutants using MCDM techniques have been addressed in Mousavi et al. (2017). Selecting green technology in the policies of countries is an effective factor in combating climate change. The purpose of this study is to evaluate and select green technology in the cement industry. According to the obtained results, lattice preheaters, furnaces with calcination apparatus and rotary cooling were selected as green technological options.

In a research to identify and prioritize the factors affecting the Technology Transfer Selection Methods, Haseli et al. (2017) used the fuzzy BWM method to study the food and beverage industry. This research has identified and prioritized the factors affecting the technology transfer methods of the industry using fuzzy BWM method in order to manage and improve the technology transfer process in the food industry [9].

Using fuzzy MADM techniques, Sadeghian and Karari (2016) have identified and prioritized the technology selection strategies. In their research, first, the concepts of strategy and technology strategy are reviewed and then, while using the SWOT method in identifying and selecting technology strategy and using multi-criteria MADM fuzzy decision-making techniques, simple fuzzy cumulative weighting in a car parts company, priorities has been given to the identified strategies and the most appropriate technology strategy has been selected [10].

After reviewing the research theoretical foundations and background, the technology selection indicators are provided in Tab. 1.

Table 1 Technology selection indicators

\begin{tabular}{|c|c|c|l|}
\hline Row & Researcher & Dimension & \multicolumn{1}{|c|}{ Indicator } \\
\hline 1 & $\begin{array}{c}\text { Drejer (1996) } \\
{[11]}\end{array}$ & $\begin{array}{l}\text { Justification of } \\
\text { productive cells }\end{array}$ & $\begin{array}{l}\text { Impact on customer } \\
\text { satisfaction, improvement } \\
\text { luring production and } \\
\text { launching cycle, speed of } \\
\text { responding to changing } \\
\text { market demands and also } \\
\text { improving the operation } \\
\text { process }\end{array}$ \\
\hline 2 & $\begin{array}{c}\text { Chan et al. } \\
(2000) \text { [10] }\end{array}$ & $\begin{array}{c}\text { Advanced } \\
\text { technology } \\
\text { selection }\end{array}$ & $\begin{array}{l}\text { Cost, performance, quality, } \\
\text { delivery, flexibility, } \\
\text { innovation }\end{array}$ \\
\hline 3 & $\begin{array}{c}\text { Hax et al. } \\
(1996) \text { [13] }\end{array}$ & $\begin{array}{c}\text { New technology } \\
\text { selection }\end{array}$ & $\begin{array}{l}\text { Effectiveness, } \\
\text { applicability, } \\
\text { implementation duration, } \\
\text { cost and risk }\end{array}$ \\
\hline 4 & $\begin{array}{c}\text { Sadeghi et al. } \\
\text { (2019) [12] }\end{array}$ & $\begin{array}{c}\text { ERP selection } \\
\text { process }\end{array}$ & $\begin{array}{l}\text { Adaptability, flexibility, } \\
\text { process improvement, } \\
\text { customer satisfaction and } \\
\text { implementation time }\end{array}$ \\
\hline 5 & $\begin{array}{c}\text { Yu-Lung } \\
(2010) \text { [14] }\end{array}$ & $\begin{array}{c}\text { Evaluating the } \\
\text { performance of the } \\
\text { production system }\end{array}$ & $\begin{array}{l}\text { Dependence, flexibility, } \\
\text { time, quality and cost }\end{array}$ \\
\hline 6 & $\begin{array}{c}\text { Saen (2006) } \\
\text { [15] }\end{array}$ & $\begin{array}{c}\text { Deciding on } \\
\text { flexible production } \\
\text { systems }\end{array}$ & $\begin{array}{l}\text { Quality, cost, productivity, } \\
\text { customer satisfaction, } \\
\text { dependence, adaptability, } \\
\text { competitiveness and top } \\
\text { management commitment }\end{array}$ \\
\hline
\end{tabular}

Table 1 Technology selection indicators (continued)

\begin{tabular}{|c|c|c|c|}
\hline Row & Researcher & Dimension & Indicator \\
\hline 7 & $\begin{array}{l}\text { Jordan et al. } \\
(2003)[16]\end{array}$ & $\begin{array}{c}\text { Software } \\
\text { evaluation } \\
\text { (CMMS) } \\
\end{array}$ & $\begin{array}{l}\text { Cost, performance, } \\
\text { implementation, reliability, } \\
\text { efficiency and reparability }\end{array}$ \\
\hline 8 & $\begin{array}{c}\text { Khalil (2000) } \\
\text { [17] }\end{array}$ & $\begin{array}{l}\text { Investigating the } \\
\text { challenges of } \\
\text { advancing the } \\
\text { operationalization } \\
\text { of the technology } \\
\text { selection } \\
\text { framework }\end{array}$ & $\begin{array}{l}\text { Reliability, quality, cost of } \\
\text { capital, }\end{array}$ \\
\hline 9 & $\begin{array}{l}\text { Liwarcin et al. } \\
\text { (2006) [18] }\end{array}$ & $\begin{array}{l}\text { Selecting new } \\
\text { technology }\end{array}$ & $\begin{array}{l}\text { Flexibility, compatibility, } \\
\text { cost, vendor, strategy } \\
\text { alignment }\end{array}$ \\
\hline 10 & $\begin{array}{l}\text { Machado et al. } \\
\text { (1997) [19] }\end{array}$ & $\begin{array}{l}\text { Evaluation and } \\
\text { selection of ERP } \\
\text { systems }\end{array}$ & $\begin{array}{l}\text { Performance, strategic } \\
\text { alignment, flexibility, user- } \\
\text { friendliness, } \\
\text { implementation time, total } \\
\text { cost and reliability }\end{array}$ \\
\hline 11 & $\begin{array}{c}\text { Torkkeli (2002) } \\
\text { [20] }\end{array}$ & $\begin{array}{l}\text { Selection of lean } \\
\text { manufacturing } \\
\text { systems }\end{array}$ & $\begin{array}{l}\text { Financial factors, } \\
\text { organizational factors, top } \\
\text { management role, impact } \\
\text { on employees, impact on } \\
\text { suppliers, impact on } \\
\text { customers, impact on } \\
\text { shareholders and projected } \\
\text { benefits }\end{array}$ \\
\hline 12 & $\begin{array}{c}\text { Torkkeli (2002) } \\
\text { [20] }\end{array}$ & $\begin{array}{c}\text { Selection of lean } \\
\text { manufacturing } \\
\text { systems }\end{array}$ & $\begin{array}{l}\text { Technology and strategic } \\
\text { fit }\end{array}$ \\
\hline 13 & $\begin{array}{l}\text { Markus et al. } \\
(2017)[21]\end{array}$ & $\begin{array}{l}\text { Selecting new } \\
\text { technology }\end{array}$ & $\begin{array}{l}\text { Productivity, quality, cost, } \\
\text { delivery, flexibility, } \\
\text { innovation and employee } \\
\text { morale }\end{array}$ \\
\hline 14 & $\begin{array}{l}\text { Mitchell et al. } \\
\text { (1985) [22] }\end{array}$ & $\begin{array}{l}\text { Selection of } \\
\text { advanced } \\
\text { production } \\
\text { technology }\end{array}$ & $\begin{array}{l}\text { Investment cost, latency, } \\
\text { capacity, space required, } \\
\text { process flexibility, product } \\
\text { quality, training, and } \\
\text { employee disturbance }\end{array}$ \\
\hline 15 & $\begin{array}{l}\text { Mohrman, et } \\
\text { al. (1990) [23] }\end{array}$ & $\begin{array}{l}\text { Selection of } \\
\text { advanced } \\
\text { production } \\
\text { technology }\end{array}$ & $\begin{array}{l}\text { Cost, flexibility, reliability, } \\
\text { quality, efficiency and the } \\
\text { impact of new technology } \\
\text { on employees }\end{array}$ \\
\hline 16 & $\begin{array}{c}\text { Khouja (2005) } \\
{[24]}\end{array}$ & $\begin{array}{l}\text { Evaluation of } \\
\text { advanced } \\
\text { production } \\
\text { technology for } \\
\text { world class }\end{array}$ & $\begin{array}{l}\text { Cost, flexibility, efficiency, } \\
\text { quality, reliability and } \\
\text { impact on human resources }\end{array}$ \\
\hline 17 & $\begin{array}{c}\text { Hax et al. } \\
\text { (1996), } \\
\text { Torkkeli } \\
(2002), \\
\text { Shehabuddeen } \\
\text { et al. }(2006) \\
{[3,11,25]} \\
\end{array}$ & Capabilities & $\begin{array}{l}\text { Technological capabilities } \\
\text { and research and } \\
\text { development background }\end{array}$ \\
\hline 18 & $\begin{array}{c}\text { Ford }(1998), \\
\text { Pegel }(1996) \\
{[11,26]} \\
\end{array}$ & Competition & $\begin{array}{l}\text { Competitive effects of } \\
\text { technology }\end{array}$ \\
\hline 19 & $\begin{array}{l}\text { Prahalad et al. } \\
\text { (1990), Watts } \\
\text { et al. (1997), } \\
\text { Radosevic } \\
(1999)[27-29] \\
\end{array}$ & Sanctions & $\begin{array}{l}\text { Political, legal and } \\
\text { executive factors of } \\
\text { economic sanctions }\end{array}$ \\
\hline
\end{tabular}

\section{RESEARCH METHOD}

The present study is an applied research in terms of the purpose because its results can be used by organizations and human societies and a descriptive research in terms of nature because the researcher does not manipulate the results 
obtained from the data. The tool used in this research is a researcher-made questionnaire. Thus, technology selection indicators in Iran's petrochemical industry after identification have been provided to research experts to agree on the most effective indicators. After the reviews, the list of agreed indicators is as follows [30, 31]: A five-point Likert scale is also used to answer the questionnaire questions. Shannon and TOPSIS entropy [32] combinations were used to data analysis.

Table 2 Technology selection indicators

\begin{tabular}{|c|c|c|}
\hline No. of expert & Experience & Education \\
\hline 1 & 40 & Bachelor degree \\
\hline 2 & 36 & MSc. \\
\hline 3 & 38 & MSc. \\
\hline 4 & 44 & Bachelor degree \\
\hline 5 & 41 & Bachelor degree \\
\hline 6 & 39 & MSc. \\
\hline 7 & 35 & MSc. \\
\hline 8 & 37 & MSc. \\
\hline
\end{tabular}

The research statistical population is consisted of managers specializing in Iran's petrochemical industry for technology transfer. The profile of these people is as it is given in Tab. 2. Variables related to the National Iranian Petrochemical Company are selected based on the Delphi method. As mentioned before, a questionnaire is designed and distributed among 8 experts. Experts comment on the Likert scale from 1 (least important) to 5 (most important).If the average opinion of experts is 4 or less, that variable is rejected and if it is 4 or higher, that variable is accepted.

\section{DATA ANALYSIS}

Twenty factors have been considered for this research based on the Delphi method (Tab. 3), of which 5 variables have been rejected and 15 variables have been accepted.

Table 3 Delphi method results

\begin{tabular}{|c|l|c|c|c|c|c|c|c|c|c|c|}
\hline Row & \multicolumn{1}{|c|}{ Indicators by importance } & Mean & Expert 1 & Expert 2 & Expert 3 & Expert 4 & Expert 5 & Expert 6 & Expert 7 & Expert 8 & Accept/reject \\
\hline 1 & Productivity & 4.375 & 4 & 5 & 5 & 4 & 3 & 4 & 5 & 5 & Accept \\
\hline 2 & $\begin{array}{l}\text { Technology complexity and technology } \\
\text { dependence }\end{array}$ & 4.5 & 5 & 4 & 3 & 5 & 4 & 5 & 5 & 5 & Accept \\
\hline 3 & Price & 4.25 & 5 & 4 & 3 & 4 & 4 & 5 & 5 & 4 & Accept \\
\hline 4 & $\begin{array}{l}\text { Knowledge transfer between internal } \\
\text { and external organizational units }\end{array}$ & 3.875 & 3 & 4 & 3 & 5 & 3 & 4 & 4 & 5 & Reject \\
\hline 5 & Need for new standard & 3.875 & 3 & 4 & 3 & 4 & 4 & 3 & 5 & 5 & Reject \\
\hline 6 & Maintenance and repair costs & 4.25 & 5 & 4 & 3 & 5 & 5 & 4 & 4 & 4 & Accept \\
\hline 7 & $\begin{array}{l}\text { Flexibility in the face of market changes } \\
\text { and customer needs }\end{array}$ & 4.25 & 3 & 3 & 4 & 4 & 5 & 5 & 5 & 5 & Accept \\
\hline 8 & Market changes and customer needs & 4.375 & 4 & 5 & 5 & 5 & 5 & 4 & 4 & 3 & Accept \\
\hline 9 & Simple operation and training of forces & 4.375 & 5 & 4 & 5 & 5 & 5 & 4 & 3 & 4 & Accept \\
\hline 10 & $\begin{array}{l}\text { Environmental compatibility and the } \\
\text { amount of pollution produced }\end{array}$ & 3.5 & 4 & 3 & 4 & 3 & 3 & 3 & 3 & 5 & \multirow{2}{*}{ Reject } \\
\hline 11 & Implementation time & 4.5 & 5 & 4 & 3 & 5 & 5 & 4 & 5 & 5 & Accept \\
\hline 12 & $\begin{array}{l}\text { Availability of cheap material and the } \\
\text { amount of material consumed }\end{array}$ & 4.375 & 5 & 4 & 3 & 4 & 4 & 5 & 5 & 5 & Accept \\
\hline 13 & Safety in operation & 4.375 & 3 & 5 & 4 & 4 & 5 & 4 & 5 & 5 & Accept \\
\hline 14 & Safety when leaving the service & 4.375 & 5 & 5 & 4 & 3 & 4 & 4 & 5 & 5 & Accept \\
\hline 15 & Safety during Shutdown & 4.375 & 5 & 4 & 3 & 5 & 5 & 5 & 4 & 4 & Accept \\
\hline 16 & $\begin{array}{l}\text { Productivity and usefulness according to } \\
\text { price }\end{array}$ & 4.625 & 5 & 4 & 5 & 5 & 4 & 5 & 4 & 5 & Accept \\
\hline 17 & Availability of executive contractors & 4.5 & 5 & 4 & 3 & 5 & 4 & 5 & 5 & 5 & Accept \\
\hline 18 & Availability of parts and manufacturers & 4.5 & 3 & 5 & 4 & 5 & 4 & 5 & 5 & 5 & Accept \\
\hline 19 & Competitive effects of technology & 3.625 & 4 & 3 & 5 & 4 & 4 & 3 & 3 & 3 & Reject \\
\hline 20 & Possibility of technology localization & 3.875 & 5 & 3 & 3 & 4 & 5 & 4 & 3 & 4 & Reject \\
\hline
\end{tabular}

Table 4 Expert weighting by Shannon entropy method

\begin{tabular}{|c|c|c|c|c|c|c|c|c|}
\hline 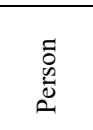 & 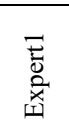 & 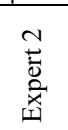 & 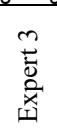 & 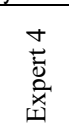 & 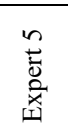 & 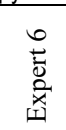 & 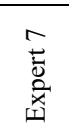 & 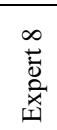 \\
\hline P1 & 6 & 6 & 8 & 4 & 6 & 8 & 5 & 8 \\
\hline $\mathrm{P} 2$ & 7 & 6 & 8 & 5 & 7 & 8 & 6 & 8 \\
\hline P3 & 8 & 6 & 8 & 5 & 7 & 8 & 5 & 8 \\
\hline P4 & 6 & 7 & 8 & 5 & 8 & 8 & 5 & 9 \\
\hline P5 & 7 & 8 & 9 & 6 & 8 & 9 & 6 & 9 \\
\hline P6 & 8 & 7 & 6 & 6 & 9 & 5 & 7 & 5 \\
\hline P7 & 9 & 4 & 7 & 7 & 9 & 6 & 7 & 6 \\
\hline P8 & 9 & 5 & 5 & 8 & 5 & 5 & 8 & 7 \\
\hline P9 & 4 & 6 & 6 & 8 & 6 & 4 & 9 & 8 \\
\hline $\mathrm{P} 10$ & 5 & 7 & 7 & 9 & 7 & 5 & 8 & 9 \\
\hline Weight & 0.08 & 0.12 & 0.1 & 0.09 & 0.18 & 0.08 & 0.09 & 0.16 \\
\hline $\mathrm{K}$ & \multicolumn{8}{|c|}{0.434294} \\
\hline
\end{tabular}

Due to the different opinions of each respondent according to their expertise and background, the weight of each opinion is different, so, the Shannon entropy method is used to obtain these weights.

In this step, we will rank the variables affecting technology transfer based on the TOPSIS method. In the first step, the decision matrix is formed. In this matrix, experts give each of the variables a number from 1 to 9 equivalent to the least to the most important.

In the second step, the matrix is normalized. This normalization is performed based on the type of index.

The decision matrix is actually parametric and needs to be quantified, and for this purpose, the decision maker determines the weight for each index. The set of weights is multiplied by the normalized matrix. 
Table 5 Initial decision matrix

\begin{tabular}{|c|c|c|c|c|c|c|c|c|}
\hline Matrix & Criterion 11 & Criterion 12 & Criterion 13 & Criterion 14 & Criterion 15 & Criterion 16 & Criterion 17 & Criterion 18 \\
\hline Production productivity & 6 & 8 & 6 & 7 & 8 & 9 & 7 & 8 \\
\hline $\begin{array}{l}\text { Technology complexity and technology } \\
\text { dependence }\end{array}$ & 6 & 8 & 7 & 9 & 9 & 8 & 7 & 5 \\
\hline Price & 9 & 8 & 7 & 7 & 9 & 8 & 9 & 8 \\
\hline Maintenance and repair costs & 9 & 8 & 7 & 8 & 7 & 8 & 7 & 6 \\
\hline $\begin{array}{l}\text { Flexibility in the face of market changes and } \\
\text { customer needs }\end{array}$ & 9 & 8 & 6 & 7 & 7 & 8 & 9 & 8 \\
\hline $\begin{array}{l}\text { Simple operation and training of specialized } \\
\text { personnel }\end{array}$ & 7 & 5 & 8 & 6 & 7 & 9 & 8 & 9 \\
\hline $\begin{array}{l}\text { Environmental compatibility and the amount } \\
\text { of pollution produced }\end{array}$ & 6 & 9 & 8 & 7 & 6 & 7 & 8 & 9 \\
\hline $\begin{array}{l}\text { Availability of cheap material and the amount } \\
\text { of material consumed }\end{array}$ & 7 & 8 & 9 & 8 & 6 & 7 & 7 & 6 \\
\hline Safety in operation & 7 & 6 & 9 & 8 & 7 & 9 & 8 & 9 \\
\hline Safety when leaving the service & 8 & 7 & 6 & 8 & 7 & 8 & 9 & 9 \\
\hline Safety during Shutdown & 8 & 7 & 6 & 8 & 9 & 8 & 9 & 7 \\
\hline Productivity and usefulness according to price & 9 & 7 & 9 & 8 & 7 & 5 & 7 & 6 \\
\hline Availability of executive contractors & 9 & 8 & 7 & 5 & 6 & 9 & 8 & 7 \\
\hline Availability of parts and manufacturers & 8 & 9 & 8 & 6 & 8 & 7 & 6 & 5 \\
\hline Technology competitive effects & 8 & 7 & 8 & 9 & 7 & 8 & 9 & 8 \\
\hline Criteria type & $\mathrm{P}$ & $\mathrm{P}$ & $\mathrm{P}$ & $\mathrm{P}$ & $\mathrm{P}$ & $\mathrm{P}$ & $\mathrm{P}$ & $\mathrm{P}$ \\
\hline Criteria weight & 0.084569 & 0.122841 & 0.195835 & 0.089413 & 0.176618 & 0.079223 & 0.091795 & 0.159704 \\
\hline Production productivity & 6 & 8 & 6 & 7 & 8 & 9 & 7 & 8 \\
\hline $\begin{array}{l}\text { Technology complexity and technology } \\
\text { dependence }\end{array}$ & 6 & 8 & 7 & 9 & 9 & 8 & 7 & 5 \\
\hline
\end{tabular}

\begin{tabular}{|c|c|c|c|c|c|c|c|c|}
\hline 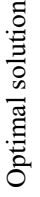 & 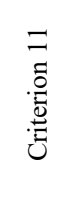 & 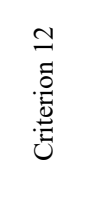 & 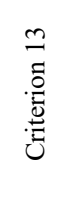 & 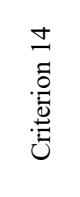 & 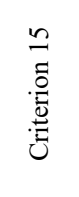 & 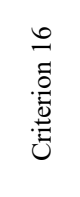 & 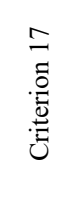 & 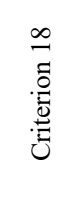 \\
\hline+ & 0.025 & 0.0375 & 0.060 & 0.027 & 0.055 & 0.023 & 0.026 & 0.049 \\
\hline- & 0.016 & 0.0209 & 0.040 & 0.014 & 0.037 & 0.012 & 0.017 & 0.027 \\
\hline
\end{tabular}

The two virtual options created are actually the worst and best solutions. The distance between each alternative is measured by the Euclidean method. That is, the distance between the alternatives and the positive and negative ideal alternatives is calculated.

In the Tab. 7, the variables are ranked based on the proximity coefficient.

Table 7 The results ranking

\begin{tabular}{|l|c|}
\hline \multicolumn{1}{|c|}{ Result } & $\begin{array}{c}\text { Proximity } \\
\text { coefficient }\end{array}$ \\
\hline Production productivity & 0.6631 \\
\hline Technology complexity and technology dependence & 0.6458 \\
\hline Price & 0.6279 \\
\hline Maintenance and repair costs & 0.5844 \\
\hline Flexibility in the face of market changes and customer needs & 0.5457 \\
\hline Simple operation and training of specialized personnel & 0.5326 \\
\hline $\begin{array}{l}\text { Environmental compatibility and the amount of pollution } \\
\text { produced }\end{array}$ & 0.5289 \\
\hline $\begin{array}{l}\text { Availability of cheap material and the amount of material } \\
\text { consumed }\end{array}$ & 0.5173 \\
\hline Safety in operation & 0.5123 \\
\hline Safety when leaving the service & 0.5113 \\
\hline Safety during Shutdown & 0.4985 \\
\hline Productivity and usefulness according to price & 0.4943 \\
\hline Availability of executive contractors & 0.4842 \\
\hline Availability of parts and manufacturers & 0.4608 \\
\hline Technology competitive effects & 0.4465 \\
\hline
\end{tabular}

\section{CONCLUSION}

As one of the most important industries, the chemical industry has been of special interest to countries in the past few decades, and this has led to its prosperity and pervasiveness in the world. It is currently the third largest industry in the world after the food and automotive industries. The variety of products and the supply of raw materials for thousands of downstream workshops and factories by it, has caused this industry to play a very effective role in the country's economy in terms of job creation, earning foreign exchange earnings and cutting dependence.

The country's petrochemical industry mechanism should be such that it faces the least challenge in financing its projects and developing this industry. Perhaps one of the most fundamental challenges facing Iran's petrochemical industry is this factor. For this purpose, first the important factors for this matter were identified based on research literature as well as interviews with experts. Then it is tried to coordinate these factors with this industry in Iran. Therefore, the Delphi method was used in which, 8 experts were asked to comment on these factors. At the beginning of the study, 20 factors were counted and based on the Delphi method, 5 factors were eliminated and 15 factors were confirmed. After screening and final identification of indicators, these factors were ranked. Since in this research, weight is considered for each expert based on specialization, degree and work experience, etc., Shannon entropy method has been used to meet this requirement.

The TOPSIS method is then used to rank these factors. According to the obtained results, the technology productivity factor has the highest priority. This means that technology with the highest level of efficiency must be transferred and used in the petrochemical industry. 
The competitive effects of technology have the lowest priority and show that in this industry, the competitive effects of technology have the least impact for technology transfer, and petrochemical companies should pay less attention to this factor. Since the research experts were the managers of this company, it was difficult to access them. As a hybrid method of Shannon and TOPSIS has been used in this research, two separate questionnaires had to be prepared and presented to the experts. Also, the number of tables in the TOPSIS method for completion by experts has been high due to the large number of criteria and sub-criteria, which has led to a decrease in the reliability of expert responses and prolongation of the research process.

The following items can be considered in future research: the model presented in this study that is implemented in the National Iranian Petrochemical Company, can be used in other industries, especially related industries such as oil, gas and refining industries, etc. This model can also be combined with other MADM methods such as WASPAS, ELECTER, MULTIMOORA, and so on.

\section{REFERENCES}

[1] APCTT. (1998). Atlas Technology: A Framework for Technology Planning. APCTT Publications.

[2] Arasti, M. R. \& Verent M. (1997). A Hierarchical Approach to Evaluation \& Selection of Strategic Technology. Proceeding of the $2^{\text {nd }}$ International Conference on Advances, 425-431.

[3] Broun, E. (1998). Technology in Context: Technology Assessment for Managers. Routledge, 70-76.

[4] Burgelman, R A., Maidique, M. A., and Wheelwright, S. C. (1995). Managing Technology and Innovation in Established Firms. Richard D. Irwin, Chicago, IL. Second Edition, 45-57.

[5] Chapelet, B. \& Tovstiga, G. (1998). Development of a Research Mythology for Assessing a Firm's Business process -Related Technologies. Journal of Technology Management, 15(1-2), 110-118. https://doi.org/10.1504/IJTM.1998.002596

[6] Chiesa, V. (2001). R\&D strategy and organization. Series on Technology Management, Vol. 5, p. 292. https://doi.org/10.1142/p223

[7] Clarke, K., et al. (1995). Technology Strategy in UK firms. Technology Analysis \& Strategic Management, 7(2), 169-190. https://doi.org/10.1080/09537329508524203

[8] Danila, N. (1989). Strategic Evaluation and Selection of R\&D Project. $R \& D$ management, 19(1), 47-62. https://doi.org/10.1111/j.1467-9310.1989.tb00615.x

[9] Drejer, A. (1996). Frameworks for the Management of Technology: Towards a Contingent Approach. Technology Analysis \& Strategic Management, 8(1), 9-20. https://doi.org/10.1080/09537329608524229

[10] Chan, F. T. S., Chan, M. H., \& Tang, N. K. H. (2000). Evaluation methodologies for technology selection. Journal of Materials Processing Technology, 107, 330-337. https://doi.org/10.1016/S0924-0136(00)00679-8

[11] Ford, D. (1998). Develop Your Technology Strategy. LongRange Planning, 21(5), 85-94. https://doi.org/10.1016/0024-6301(88)90109-4

[12] Sadeghi, A., Azar, A., Valmohammadi, C., \& Alirezaei, A. (2019). Designing a product-service supply chain performance evaluation model in the home appliance industry using factor analysis and fuzzy neural networks Case study: home appliance companies in Iran. Journal of Production and Operations Management, 10(2), 83-123. https://doi.org/10.22108/jpom.2019.116300.1193.

[13] Hax, A. C. \& Majluf, N. S. (1996). The Strategy Concept \& Process: A Pragmatic Approach. Prentice Hall

[14] Hsu, Y.-L., Lee, C.-H., \& Kreng, V. B. (2010). The application of Fuzzy Delphi Method and Fuzzy AHP in lubricant regenerative technology selection. Expert Systems with Applications, 37, 419-425. https://doi.org/10.1016/j.eswa.2009.05.068

[15] Saen, R. F. (2006). A decision model for technology selection in the existence of both cardinal and ordinal data. Applied Mathematics and Computation, 181, 1600-1608. https://doi.org/10.1016/i.amc.2006.03.012

[16] Jordan, J., Watkins, A., Fleming, G. South, B., Schwartz, R., Oglesby, D., Ingram, J., \& Tominack, B. (2003). Development of Rapid Technology Assessment Tools-A New Paradigm in Aerodynamic Design. Proceedings of the $49^{\text {th }}$ International Instrumentation Symposium.

[17] Khalil, T. M. (2000). Management of Technology: The Key to Competitiveness and Wealth Creation. McGraw Hill.

[18] Liwarcin, O. \& Soyak, B. (2006). A new approach for the diagnosis of strategic problems in technology management. PICMET, Portland International Conference on Management of Engineering and Technology, Istanbul, Turkey, July, 8-13. https://doi.org/10.1109/PICMET.2006.296552

[19] Machado, F. M. (1997). Technology Management for LeapFrogging Industrial Development: The Challenge for Developing Countries at the Beginning of the New Millennium. UNIDO, Vienna

[20] Torkkeli, M. \& Tuominen, M. (2002). The contribution of technology selection to core competencies. Int. J. Production Economics, 77, 271-284. https://doi.org/10.1016/S0925-5273(01)00227-4

[21] Markus, L. \& Jacob, S. (2017). Strategic technology adoption and hedging under incomplete markets. Journal of Banking \& Finance, 81, 181-199. https://doi.org/10.1016/j.jbankfin.2016.09.008

[22] Mitchell, G. R. (1985). A New Approach for the Strategic Management of Technology. Technology in Society, 7, 227239. https://doi.org/10.1016/0160-791X(85)90027-2

[23] Von Glinow, M. A. \& Mohrman, S. A. (Eds.) (1990). Beyond the Clash: Managing High Technology Professionals. In Managing Complexity in High Technology Organizations. Oxford University press, 3-14.

[24] Khouja, M. (2005). Joint inventory and technology selection decisions. Omega, 33(1), 47-53. https://doi.org/10.1016/j.omega.2004.03.006

[25] Shehabuddeen, N., Probert, D., \& Phaal, R. (2006). From theory to practice: challenges in operationalising a technology selection framework. Technovation, 26, 324-335. https://doi.org/10.1016/j.technovation.2004.10.017

[26] Pegels, C. C. \& Thirumurthy, M. V. (1996). The Impact of Technology Strategy on Firm Performance. IEEE Transaction on Engineering Management, 43(3), 246-249. https://doi.org/10.1109/17.511835

[27] Prahalad, C. K. \& Hamel, G. (1990). The Core Competence of the Corporation. Harvard Business Review, May-June, 79-91.

[28] Watts, R. J. \& Porter, A. L. (1997). Innovation Forecasting. Technological Forecasting and Social Change, 56, 25-47. https://doi.org/10.1016/S0040-1625(97)00050-4

[29] Radosevic, S. (1999). International Technology Transfer and Catch-up in Economic Development. Edward Elgar Pub.

[30] Sharif, N. (1986). Technology Policy Formulation and Planning. Bangalore, India: APCTT.

[31] Stieglitz, J. E. (1998). More instruments and broader goals: moving toward the Post-Washing consensus. WIDER Annual 
Lectures 2, World Institute for Development Economics Research, The United Nations University, Helsinki, Finland.

[32] UNIDO. (2019). Technology Needs Assessment (TNA) for Developing Countries.

Authors' contacts:

Seyed Hossein Nouri, M.Sc. Student Faculty of Management, Islamic Azad University,

Central Tehran Branch, Azadi Str., 123456 Tehran, Iran

Dr. Tahmoures Sohrabi, Assistant Professor (Corresponding Author)

Faculty of Management, Islamic Azad University,

Central Tehran Branch, Azadi Str., 123456 Tehran, Iran

dr.tahmoures.sohrabi@gmail.com 